\title{
Pectobacterium carotovorum subsp. brasiliense Causes Soft Rot and Death of Neobuxbaumia tetetzo in Zapotitlan Salinas Valley, Puebla, Mexico
}

\author{
Dimas Mejía-Sánchez, ${ }^{1}$ Sergio Aranda-Ocampo, ${ }^{1, \dagger}$ Cristian Nava-Díaz, ${ }^{1}$ Daniel Teliz-Ortiz, ${ }^{1}$ Manuel Livera-Muñoz, ${ }^{2}$ Rodolfo De La \\ Torre-Almaráz, ${ }^{3}$ and Samuel Ramírez-Alarcón ${ }^{4}$ \\ ${ }^{1}$ Fitosanidad, Colegio de Postgraduados Texcoco, México, 56230; ${ }^{2}$ Genética, Colegio de Postgraduados Texcoco, México, \\ 56230; ${ }^{3}$ Universidad Nacional Autónoma de México, UBIPRO, FES Iztacala, México; ${ }^{4}$ Departamento de Parasitología Agrícola, \\ Universidad Autónoma Chapingo, Texcoco, México, 56230
}

\begin{abstract}
Neobuxbaumia tetetzo (Coulter) Backeberg (tetecho) is a columnar cactus endemic to Mexico. Tetecho plants, flowers, fruits, and seeds play an important role in the semiarid ecosystem, as they serve as a refuge and food for insects, bats, and birds, and are widely used by ethnic groups since pre-Hispanic times. Tetecho is affected by a soft rot that damages the whole plant and causes its fall and disintegration. Eight bacterial colonies of similar morphology were isolated from plants showing soft rot and inoculated in healthy tetecho plants, reproducing typical symptoms of soft rot 9 days after inoculation. Ten representative isolates

were selected for phenotypic and genetic identification using $16 \mathrm{~s}$ rDNA, IGS 16S-23S rDNA, and rpoS genes and for pathogenicity tests on several members of the cactus family and other plants. Based on the results, these bacterial isolates were identified as Pectobacterium carotovorum subsp. brasiliense. Inoculation of this bacteria caused soft rot in different cacti, fruits, leaves, and roots of other plants. This is the first report of the subspecies brasiliense of $P$. carotovorum causing soft rot and death in cacti in the world and the first report of this subspecies in Mexico.
\end{abstract}

Mexico is considered the country with the highest Cactaceae diversity with 913 taxa described, of which $80 \%$ are endemic to the country (Leonor and Sierra 2011). The Tehuacan-Cuicatlan Biosphere Reserve in Mexico is a semiarid region with the greatest diversity of endemic species of animals, plants, and microorganisms. An important group are columnar cacti (Leonor and Sierra 2011) where Neobuxbaumia tetetzo (Coulter) Backeberg stands out because of its abundance in Zapotitlan Salinas Valley, Puebla $\left(18^{\circ} 20^{\prime} \mathrm{N}, 97^{\circ} 28^{\prime} \mathrm{W}\right)$ (Arias et al. 2017).

Tetecho occupies areas of up to $400 \mathrm{~km}^{2}$ and population densities of 1,200 to 1,800 plants per hectare (Ruedas et al. 2006). The average lifespan of tetecho is 110 to 120 years. This cactus plays a fundamental ecological role within the ecosystem because from mid-April to June, the apex of the plant produces flowers, nectar, and pollen that feeds birds, insects, and bats that pollinate and disperse seeds throughout the area (Godínez 2011). Tetecho is an important source of food for ethnic groups that use flower buds, fruits, and seeds to prepare approximately 50 regional dishes. The Tetecho Regional Fair is held annually in May to show the diversity of uses of the plant. Even the dead plants are used as fuel and wood to build rustic huts (Godínez 2011).

One of the main factors that threatens tetecho is soft rot disease. During field trips to Zapotitlán Salinas Valley, Puebla, it was observed that tetecho plants showed areas of yellowish tissue and soft rot, stem rupture, and exudates. Soft rot expands throughout the plant and causes disintegration of tissues, collapse, and death; young plants may be affected. Due to the characteristics of these symptoms, the soft rot, collapse, and death of the tetecho could be caused by bacteria. The only information regarding this problem in tetecho in Mexico was contributed by Tovar (2011), who associated this symptom to borer insects and bacteria that accelerate tetecho death; however,

${ }^{\dagger}$ Corresponding author: S. Aranda-Ocampo; E-mail: saranda@colpos.mx

Funding: The authors would like to thank the National Council of Science and Technology (CONACyT) for the economic support to develop the research.

Accepted for publication 14 August 2018.

C 2019 The American Phytopathological Society there are no descriptive records of insects nor bacteria that cause death of this cactus.

Considering the ecological importance of tetecho, the goal of this research was to identify the pathogen that causes soft rot and death of tetecho in Zapotitlan Salinas Valley, Puebla, Mexico.

\section{Materials and Methods}

Isolation. Tetecho plants in Zapotitlan Salinas Valley, Puebla, Mexico, were surveyed from 2015 to 2017 . Eighty samples of tetecho plants that showed symptoms of soft rot were collected. Tissue sections of approximately $0.5 \mathrm{~cm}^{2}$ from the transition zone between rotten and healthy tissue were disinfested using $1 \%$ sodium hypochlorite $(\mathrm{v} / \mathrm{v})$ for $1 \mathrm{~min}$ and then washed with autoclaved distilled water. To isolate bacteria, disinfested tissue was placed into nutrient broth $(\mathrm{NB})$ and casaminoacid-peptone-glucose (CPG) media, as well as in buffer solution (Tris-EDTA). Additionally, exudates from diseased tetecho stems were directly collected in the field and placed in tubes that contained $5 \mathrm{ml}$ of autoclaved distilled water, and $20 \mu \mathrm{l}$ of this mix were inoculated in the laboratory into NB culture medium; inoculated media was incubated at $18^{\circ} \mathrm{C}$ for $48 \mathrm{~h}$. Twenty microliters of each culture media were transferred to King's B (KB), Reasoner's 2A agar (R2A), and nutrient agar (NA) media. Suspensions were distributed on the media using a Drigralsky spreader and incubated as described above. Eighty bacterial isolates with similar morphology were recovered. Pure bacterial colonies were preserved in CPG medium at $-20^{\circ} \mathrm{C}$ (Schaad et al. 2001).

Pathogenicity test. The 80 isolates were inoculated on potato slices (Solanum tuberosum L. var. Fiana) and tetecho plants (two slices of tuber and two cacti per isolate). Potato tubers were disinfested using $1 \%$ sodium hypochlorite for $1 \mathrm{~min}$ and washed with autoclaved distilled water; 4-cm diameter and 5-mm thick slices were cut and placed in a Petri dish that contained a piece of sterile Whatman \#1 filter paper and water. Twenty $\mu \mathrm{L}$ of an aqueous bacterial suspension with an approximate cell density of $1.5 \times 10^{6} \mathrm{CFU} \mathrm{ml} \mathrm{m}^{-1}(0.2$ absorbance at $580 \mathrm{~nm}$ ) were placed on the center of slices and incubated at $28^{\circ} \mathrm{C}$ for $72 \mathrm{~h}$. Controls were inoculated with autoclaved distilled water. One hundred and sixty tetecho plants that were 5 years old and $8 \mathrm{~cm}$ in height produced in certified nurseries in Zapotitlán, Puebla, were inoculated by injecting $20 \mu \mathrm{l}$ of the bacterial suspensions as described previously (Stommel et al. 1996). The surface of the plants was disinfested using $70 \%$ ethanol (v/v) and washed with autoclaved distilled water prior to inoculation. Plants were maintained under 
greenhouse conditions $\left(25\right.$ to $30^{\circ} \mathrm{C}, \mathrm{RH} 80 \%$, with natural light, for 10 days). Thirty tetecho plants that were inoculated with $20 \mu 1$ autoclaved distilled water were used as a control. From the 80 isolates that induced soft rot on potato tubers and tetecho plants, 10 selected bacterial isolates (Tet5, Tet16, Tet24, Tet36, Tet52, Tet60, Tet61, Tet72, Tet75, and Tet77) were randomly selected and inoculated by injecting $20 \mu \mathrm{l}$ of the bacterial suspension $\left(1.5 \times 10^{6} \mathrm{CFU} \mathrm{ml}{ }^{-1}\right)$ into seven cactus species (surface disinfested with alcohol as described above): Myrtillocactus geometrizans, Mammillaria magnimamma, Mammillaria discolor, Gymnocalycium horstii, Pachicereus marginatus, Opuntia rufida, and Opuntia ficus-indica. Plants inoculated with autoclaved distilled water were used as a control. The cacti were maintained under the greenhouse conditions described above. To test the ability to macerate tissue from other plant species, fruits, leaves, or roots, the isolates were also inoculated by injection $(20 \mu \mathrm{l} ; 1.5 \times$ $10^{6} \mathrm{CFU} \mathrm{m} \mathrm{m}^{-1}$ ) on disinfested ( $2 \%$ sodium hypochlorite for $2 \mathrm{~min}$ and washed with autoclaved distilled water) fruits of Capsicum annuum var. annuum, Solanum lycopersicum, Cucumis sativus, leaves of Lactuca sativa, and roots of Daucus carota subsp. sativus and Ipomoea batatas and placed in a moisture chamber at $28^{\circ} \mathrm{C}$ for 4 days.

Phenotypic characterization. The isolates were characterized and identified according to Schaad et al. (2001) and Czajkowski et al. (2015). Sensitivity to 12 antibiotics was evaluated (Bio-Rad,
CA, U.S.A.) and biochemical profiles were determined using API20 E (Biomerieux, Durhan, NC, U.S.A.)

Molecular characterization. DNA extraction. DNA from the isolates was obtained from single colonies that grew $24 \mathrm{~h}$ in CPG medium at $28^{\circ} \mathrm{C}$, using PureLink Genomic DNA Kits (Invitrogen Life Technologies, Carlsbad, CA, U.S.A.) following manufacturer's instructions.

$16 S$ rDNA sequencing. Universal primers $8 \mathrm{~F}$ (5'-AGAGTTTG ATCCTGGCTCAG-3') and 1492R (5'-GGTTACCTTGTTACG ACTT-3') were used to amplify and to sequence 16S rRNA gene from the isolates. Polymerase chain reaction (PCR) was carried out in a final volume of $50 \mu \mathrm{l}$, with $1 \times$ PCR Buffer, $1.5 \mathrm{mM} \mathrm{MgCl}$, $0.2 \mathrm{mM}$ of each dNTP, $0.6 \mu \mathrm{M}$ of each oligonucleotide, $1.5 \mathrm{U}$ of Taq polymerase (Invitrogen), and $10 \mathrm{ng}$ of template DNA. PCR conditions were initial denaturation at $95^{\circ} \mathrm{C}$ for $5 \mathrm{~min}$, followed by 30 cycles of denaturation at $94^{\circ} \mathrm{C}$ for $50 \mathrm{~s}$, annealing at $57^{\circ} \mathrm{C}$ for $30 \mathrm{~s}$, extension at $72^{\circ} \mathrm{C}$ for $90 \mathrm{~s}$, and final extension at $72^{\circ} \mathrm{C}$ for $5 \mathrm{~min}$ (Eden et al. 1991). Aliquots of $5 \mu \mathrm{l}$ were analyzed by electrophoresis in $1.5 \%(\mathrm{w} / \mathrm{v})$ agarose (Promega, Madison, WI, U.S.A.) in TBE buffer. Gels were stained with ethidium bromide and visualized in a gel documentation (DNR minibus-pro). Amplicons were purified from the gel using Wizard SV gel and PCR Clean-Up System Kit (Promega), following manufacturer's instructions, and sequenced
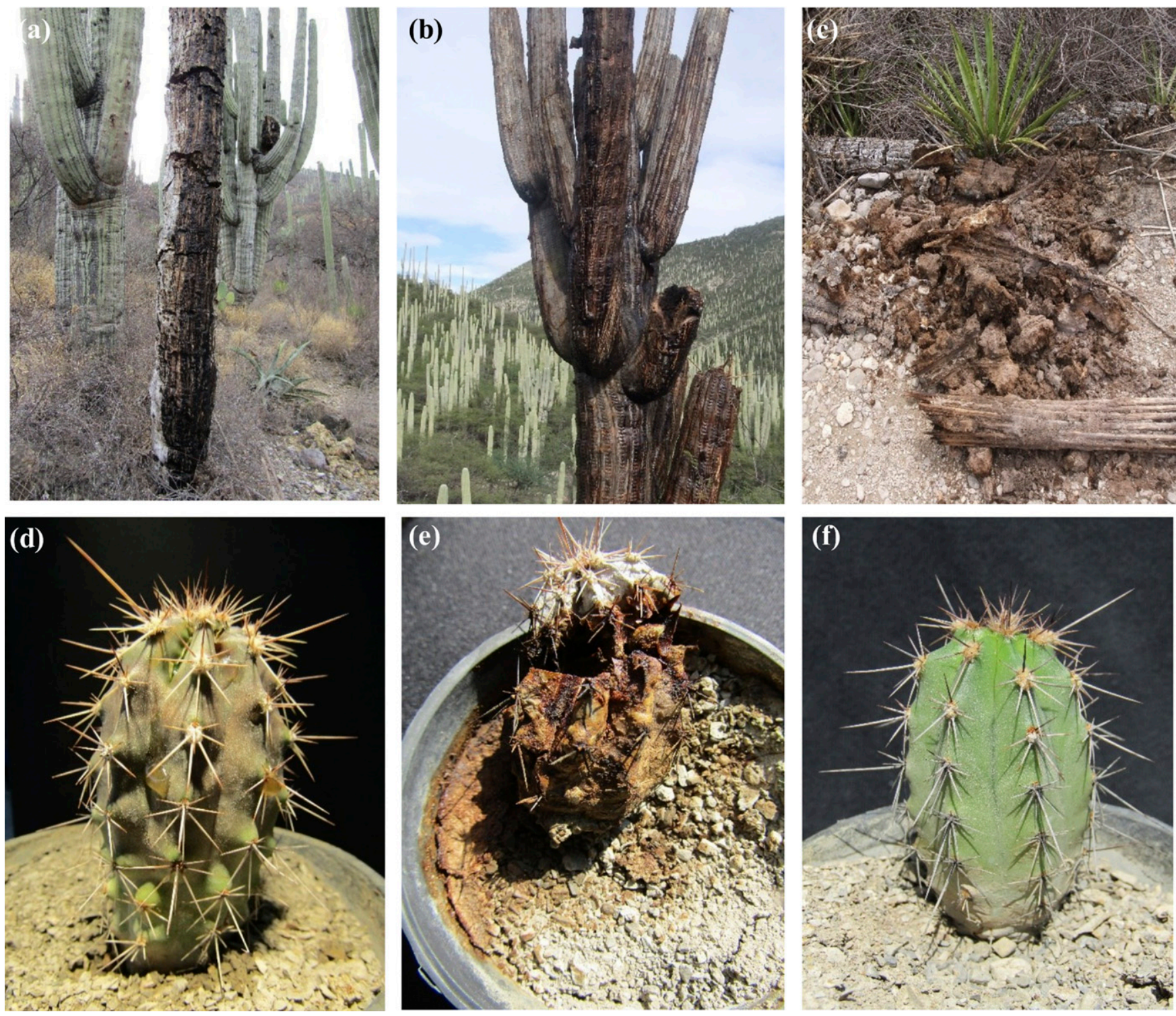

Fig. 1. Symptoms of soft rot and exudate in tetecho plants in Zapotitlan Salinas Valley, Puebla, Mexico: (a) plants showing soft rot, (b) plants showing exudates, (c) collapse and disintegration of tissue. Symptoms in inoculated tetecho plants under greenhouse conditions: (d) soft rot and exudates 7 days after inoculation (dai), (e) tetecho collapse 9 dai, (f) control plants without symptoms. 
in a Genetic Analyzer 3100 (Applied Biosystems Corp., Foster City, CA, U.S.A.).

IGS 16S-23S rDNA sequencing. Intergenic spacer region (IGS) $16 \mathrm{~S}-23 \mathrm{~S}$ rDNA from the isolates was tested using specific primers for Pectobacterium carotovorum subsp. brasiliense BR1f ( $5^{\prime}$ GCGTGCCGGGTTTATGACCT-3') and L1r (5'-CAAGGCATCCACCGT- $3^{\prime}$ ). BR1f was designed from IGS region based on restriction enzyme SEXA1 and L1r was designed from the $5^{\prime}$ end of the $23 \mathrm{~S}$ rRNA gene (Duarte et al. 2004). PCR was carried out in a final volume of $50 \mu \mathrm{l}$ with $1 \times$ PCR buffer, $2 \mathrm{mM} \mathrm{MgCl} 2,0.1 \mathrm{mM}$ of each $\mathrm{dNTP}, 0.3 \mu \mathrm{M}$ of each oligonucleotide, $1.5 \mathrm{U}$ Taq polymerase (Invitrogen), and 10 ng template DNA. PCR conditions were initial denaturation at $94^{\circ} \mathrm{C}$ for $2 \mathrm{~min}$, followed by 30 cycles of denaturation at $94^{\circ} \mathrm{C}$ for $30 \mathrm{~s}, 62^{\circ} \mathrm{C}$ for $45 \mathrm{~s}, 72^{\circ} \mathrm{C}$ for $90 \mathrm{~s}$, and final extension at $72^{\circ} \mathrm{C}$ for $7 \mathrm{~min}$ (Choi and Kim 2013). Amplified products were visualized by electrophoresis in a $2 \%$ agarose gel (Promega). Amplicons were purified from the gel using Wizard SV gel and PCR Clean-Up System kit (Promega) and sequenced in a Genetic Analyzer 3100 (Applied Biosystems Corp.). Sequences were analyzed and compared with similar sequences available at the National Center for Biotechnological Information (GenBank-EMBL) (Altschul et al. 1990). Primers Br1f and L1r were used for amplification on DNA extracted from tetecho tissue that showed symptoms of soft rot collected in Zapotitlan Salinas Valley. Negative controls included $P$. carotovorum subsp. carotovorum, P. atrosepticum, and Dickeya chrysanthemi strains obtained from the Plant Pathology Bacteria Laboratory at the College of Postgraduates.

rpoS sequencing. Identity of the isolates was confirmed by sequencing the $\sigma$ subunit of the RNA polymerase factor 38 (rpoS) using primers rpoS1 (ATGAGCCAAAGTACGCTGAA) and rpoS2 (ACCTGAATCTGACGAACACG) (Waleron et al. 2002). PCR was carried out in a final volume of $50 \mu l$ with $1 \times$ PCR buffer, $2.5 \mathrm{mM} \mathrm{MgCl}_{2}, 0.2 \mathrm{mM}$ of each dNTP, $0.3 \mu \mathrm{M}$ of each oligonucleotide, $2 \mathrm{U}$ Taq polymerase (Invitrogen), and $10 \mathrm{ng}$ of template DNA. PCR conditions were initial denaturation at $95^{\circ} \mathrm{C}$ for $3 \mathrm{~min}$, followed by 32 cycles of denaturation at $94^{\circ} \mathrm{C}$ for $1 \mathrm{~min}, 55^{\circ} \mathrm{C}$ for $50 \mathrm{~s}, 72^{\circ} \mathrm{C}$ for $2 \mathrm{~min}$, and final extension of $72^{\circ} \mathrm{C}$ for $6 \mathrm{~min}$ (Waleron et al. 2002). Amplicons were visualized by electrophoresis in $2 \%$ agarose gel (Promega). Amplicons were purified using Wizard SV gel and PCR Clean-Up System Kit (Promega), following manufacturer's instructions and sequenced in a Genetic Analyzer 3100 (Applied Biosystems Corp.). Sequences were compared using the BLAST tool at the National Center for Biotechnology Information (GenBankEMBL) (Altschul et al. 1990). Consensus sequences obtained in this research were deposited in GenBank. The rpoS sequences from the isolates were compared with sequences obtained from NCBI (accession nos. KP762578, KP762579, KJ818457, JF926832, KJ818464, and JN600353) and analyzed using the maximum-likelihood method and the neighbor-joining model in MEGA 6 (Tamura et al. 2013).

\section{Results}

Symptoms and pathogenicity. Typical symptoms of soft rot, collapse, and death were observed in tetecho plants in Zapotitlan Salinas Valley, Puebla, Mexico (Fig. 1a, b, and c). From tetecho plants that showed typical symptoms of soft rot and exudates, 80 bacterial strains with similar morphology (Tet1-Tet80) were isolated. Bacteria grew on NA, CPG, and KB media. Isolates showed pectinolytic activity on potato slices. Soft rot was observed on inoculated tetecho plants under greenhouse conditions (Fig. 1d and e). In these tetecho plants, exudates were observed 2 days after inoculation (dai), and soft rot was observed in the whole plant 7 and 9 dai when plants collapsed and died. Inoculated bacteria were successfully reisolated from rotten, inoculated tetecho plants showing the same morphological characteristics, fulfilling Koch's postulates. Identity was confirmed by phenotypic characterization, and PCR using specific primers BR1f and L1r (Duarte et al. 2004). No symptoms were observed in control plants (Fig. 1f).

The isolates caused soft rot on cacti Myrtillocactus geometrizans (Fig. 2a), Opuntia rufida, Opuntia ficus-indica, Gymnocalycium horstii (Fig. 2b), Pachicereus marginatus (Fig. 2c), Mammillaria magnimamma, Mammillaria discolor, and on fruits of Capsicum annuum var. annuum (Fig. 2d), Solanum lycopersicum (Fig. 2e), Cucumis
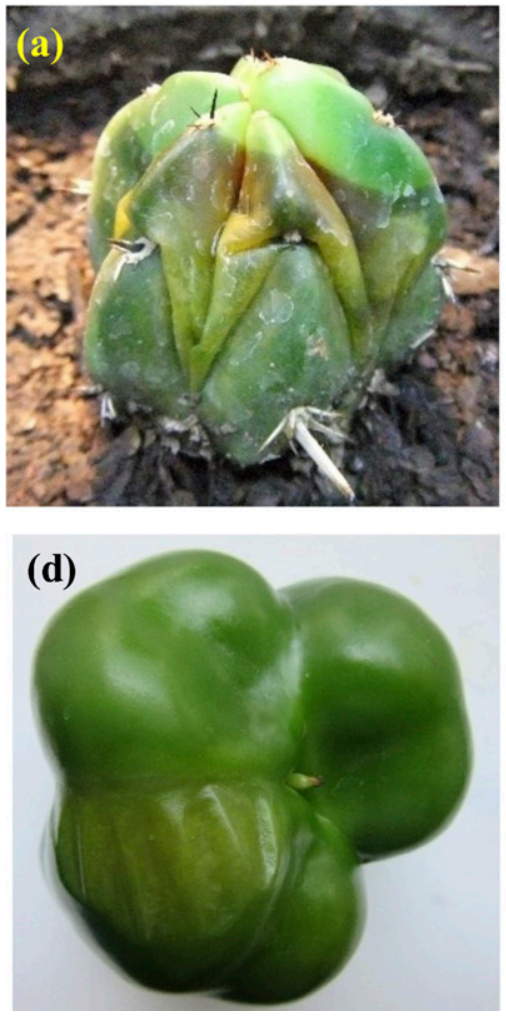
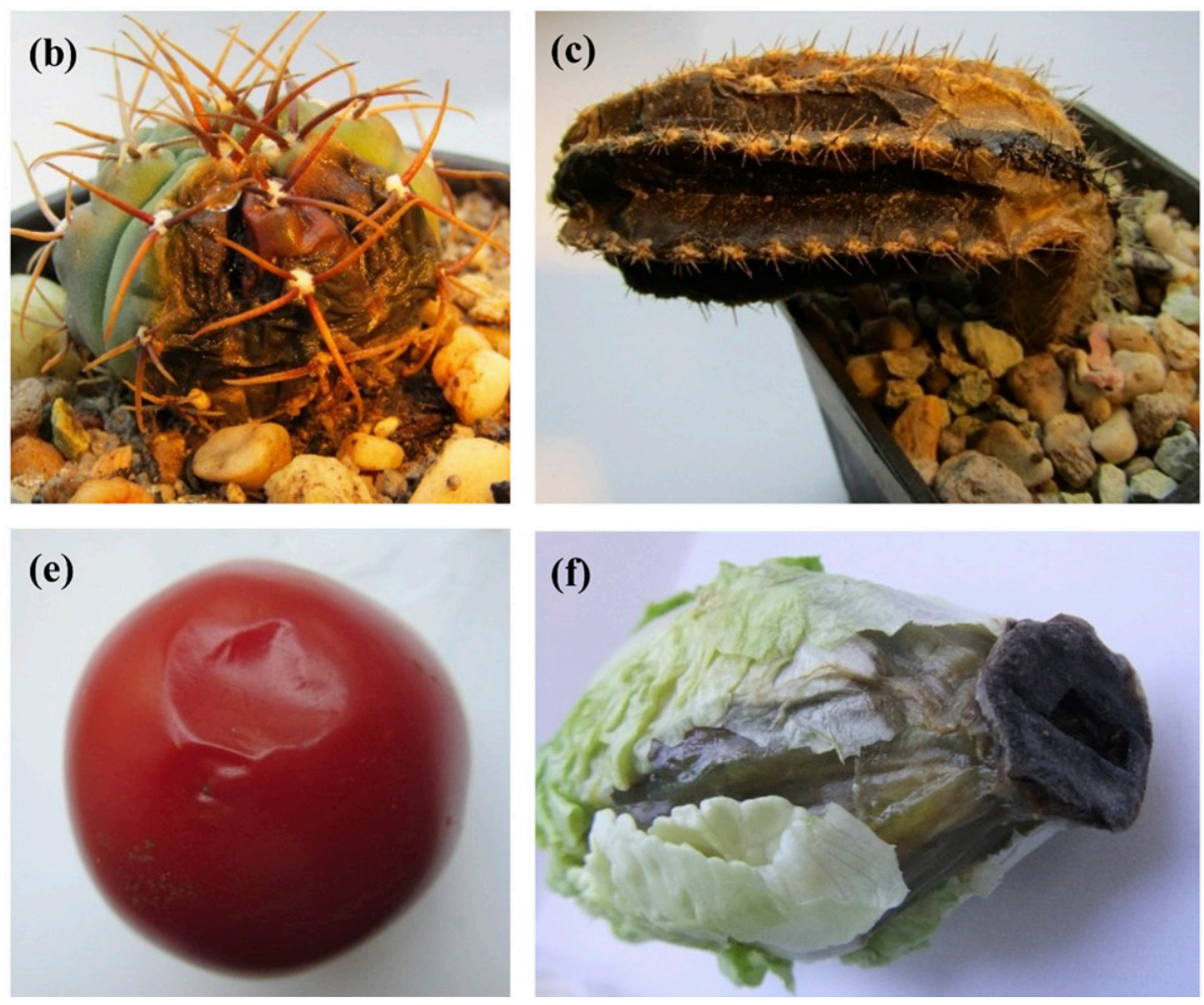

Fig. 2. Soft rot symptoms observed 2 days after inoculation on (a) Myrtillocactus geometrizans, (b) Gymnocalycium horstii, (c) Pachicereus marginatus, fruits of (d) Capsicum annuum var. annuum, (e) Solanum lycopersicum, and leaves of (f) Lactuca sativa. 
sativus, leaves of Lactuca sativa (Fig. 2f), and roots of Daucus carota subsp. sativus and Ipomoea batatas. Soft rot was observed 2 dai and collapse occurred 4 dai. Fruits of Cucurbita pepo and Physalis ixocarpa and leaves of Brassica oleracea var. capitata did not show symptoms. None of the controls showed symptoms and the inoculated bacteria were successfully reisolated from inoculated plants and organs.

Phenotypic characterization. The isolates formed circular colonies, gray in color, convex and wet in appearance. Cells were bacillar, mobile, and Gram negative. Isolates were facultative anaerobes, did not fluoresce on $\mathrm{KB}$ medium, grew at $37^{\circ} \mathrm{C}$ in $\mathrm{NB}$ and $\mathrm{CPG}$ culture media, did not produce sucrose-reducing substances and indole, and produced acid from lactose, maltose, $\alpha$-methyl glucoside, and trehalose, but not from sorbitol. Isolates tolerated $7 \% \mathrm{NaCl}$ in $\mathrm{NB}$ and CPG and they were sensitive to amicasin, ampicillin, cephaletin, cefinaxone, chloramphenicol, enonaxin, gentamicin, notilmicin, and trimethoprim-sulfatomethoxasol. Isolates were not sensitive to penicillin, erythromycin, and dicloxacillin. No differences were observed in the phenotypic characterization.

Molecular characterization. Sequences of the 16S rRNA gene from the isolates (consensus sequence with accession numbers MF403054, MG818833-MG818841) indicated 99\% similarity to P. carotovorum subsp. brasiliense (accession no. CP020350). Using specific primers BR1f and L1r (Duarte et al. 2004) it was possible to amplify a 381-bp fragment from the isolates and tissue samples from the field that showed typical symptoms. Similar results were reported by Choi and Kim (2013). It was not observed in amplicons using the reference strains $P$. carotovorum subsp. carotovorum, $P$. atrosepticum, and D. chrysanthemi (Fig. 3).

Amplified sequences from the IGS 16s-23S rDNA region and $\sigma$ subunit of RNA polymerase factor 38 ( rpoS) obtained from the isolates showed from 99 to $100 \%$ (accession nos. MG825334-MG825343

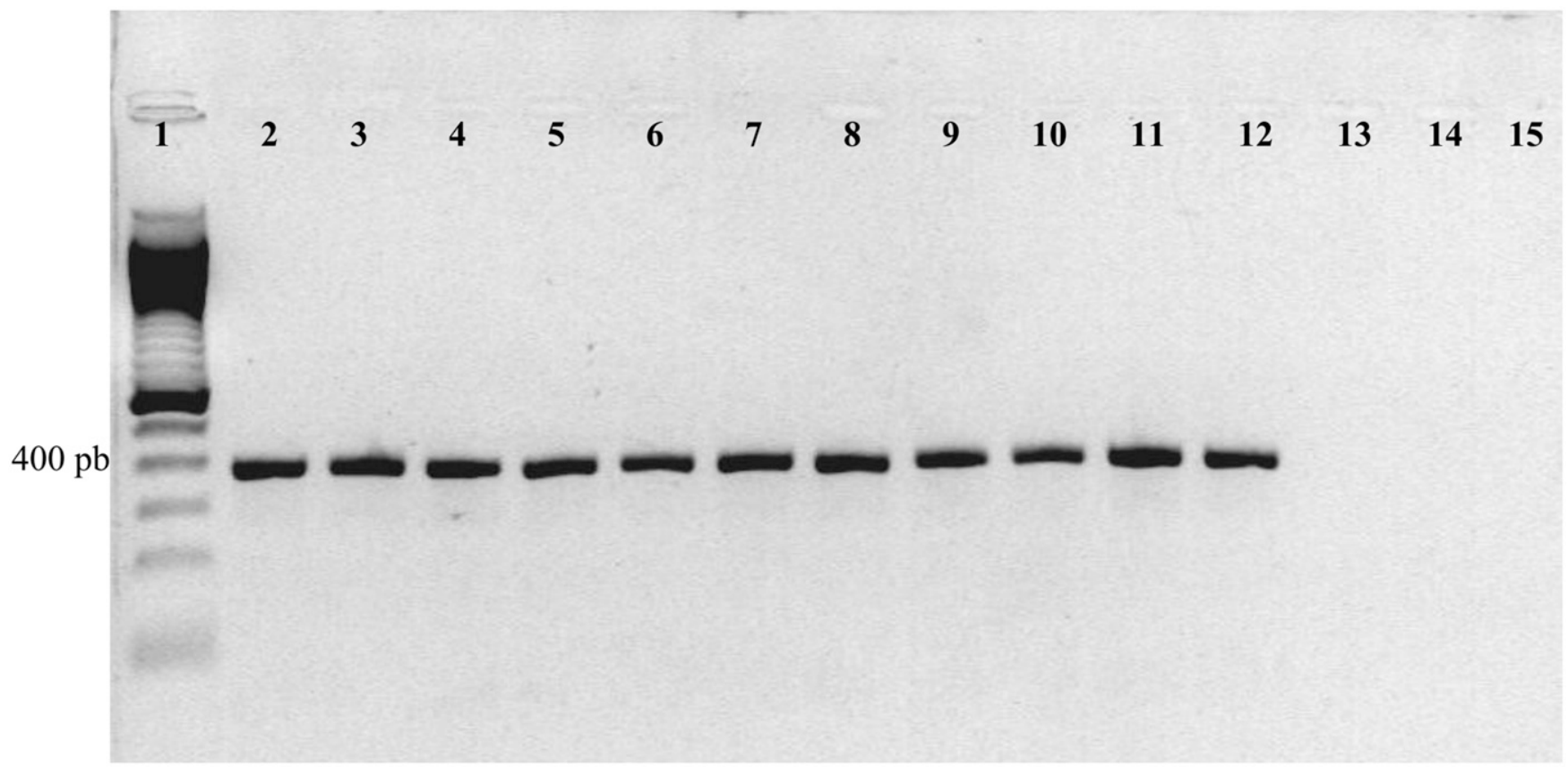

Fig. 3. Amplicons of $381 \mathrm{bp}$ observed using BR1f and L1r primers from the IGS 16S-23S region obtained from 10 selected isolates (2-11) and field tissue samples that show typical symptoms (12). No amplicons were observed on Pectobacterium carotovorum subsp. carotovorum (13), P. atrosepticum (14), and Dickeya chrysanthemi (15) strains. 100 bp ladder lane 1.

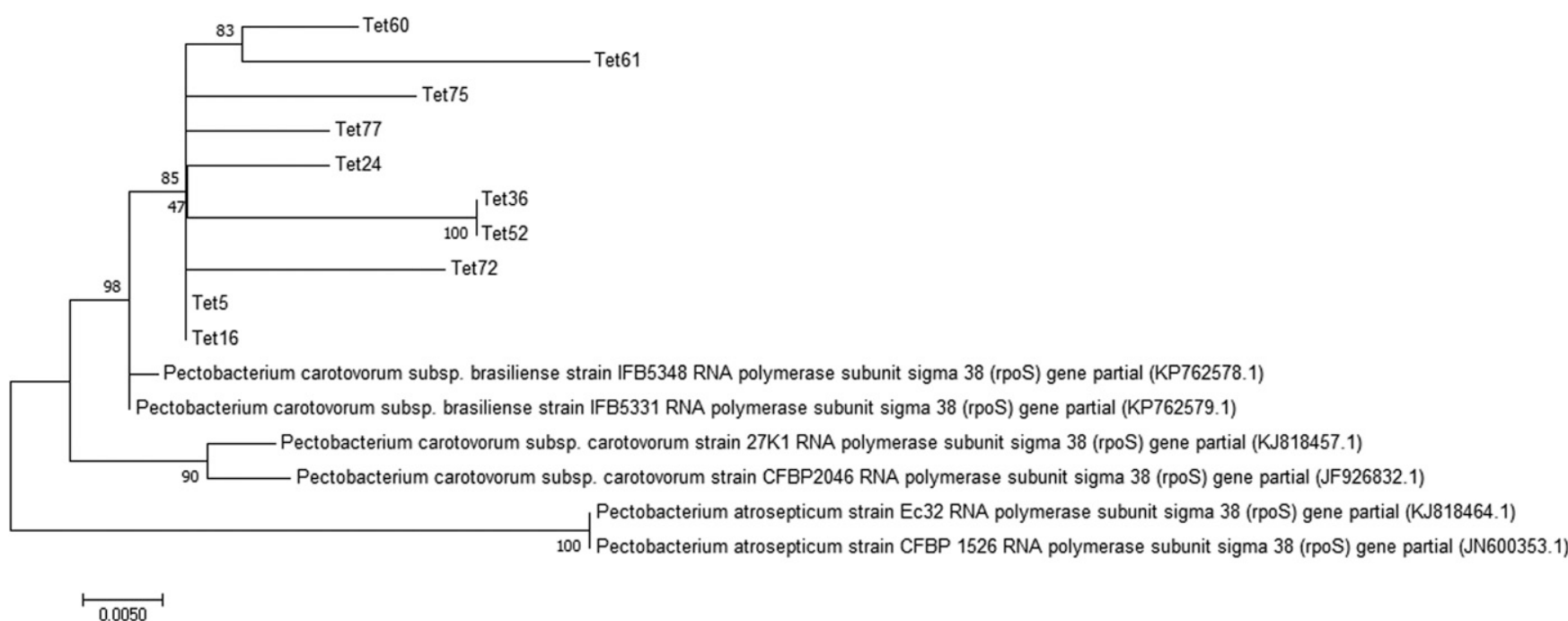

Fig. 4. Phylogenetic analysis (maximum-likelihood method) using rpoS sequences of 10 isolates from tetecho and available sequences of the same gene of Pectobacterium carotovorum subsp. brasiliense, P. carotovorum subsp. carotovorum, and P. atrosepticum. 
and MG963906-MG963915) similarity to P. carotovorum subsp. brasiliense (accession nos. AF448592 and JF926836).

Phylogenetic analysis (maximum-likelihood method) using rpoS sequences of the isolates showed a compact cluster with $P$. carotovorum subsp. brasiliense (accession nos. KP762578 and KP762579), separated from $P$. carotovorum subsp. carotovorum and P. atrosepticum. Variability was observed within tetecho isolates using the rpoS gene (Fig. 4).

Based on pathogenicity, phenotypical, and molecular characterization, the causal agent of soft rot, collapse, and death that affects tetecho plants in Zapotitlan Salinas Valley, Puebla, Mexico, is $P$. carotovorum subsp. brasiliense.

\section{Discussion}

P. carotovorum subsp. brasiliense was identified as the causal agent of soft rot, collapse, and death of tetecho in Zapotitlan Salinas Valley, Puebla, Mexico. P. carotovorum subsp. brasiliense was first described in Brazil causing "black leg" on potato (Solanum tuberosum L.) (Duarte et al. 2004). P. carotovorum subsp. brasiliense has been reported as an emerging bacterium causing "black leg" of potato in New Zealand (Panda et al. 2012), Canada (De Boer et al. 2012), South Africa (van der Merwe et al. 2010), and Holland (Nunes Leite et al. 2014). P. carotovorum subsp. brasiliense has a wide host range, and the bacterium has been reported on cucumber (Cucumis sativus L.) (Onkendi et al. 2016), tomato (Solanum lycopersicum L.) (Jaramillo et al. 2017), beetroot (Beta vulgaris L.), cabbage (Brassica oleracea var. capitata), zucchini (Cucurbita pepo L.) (Waleron et al. 2015), and pepper (Capsicum annuum var. annuum) (Gillis et al. 2017). In this research, P. carotovorum subsp. brasiliense isolated from tetecho that was inoculated on Cucurbita pepo and Brassica oleracea var. capitata did not induce soft rot. Similar results have been reported by Waleron et al. (2015). Also, Alcorn et al. (1991) found differences in the pectinolitic activity of 108 bacteria ( $P$. carotovorum subsp. brasiliense not included) isolated from cacti from distinct geographical origin. They observed different abilities of the bacteria to produce soft rot within the same genetic group when inoculated in tomato fruit, potato tuber, and carrot root (Daucus carota).

$P$. carotovorum subsp. brasiliense was described as a new subspecies of $P$. carotovorum due to its phenotypic and genetic characteristics, and higher virulence and aggressiveness compared with P. carotovorum, P. atrosepticum, $P$. betavasculorum, $P$. wasabiae, and Dickeya spp. (Duarte et al. 2004; van der Wolf et al. 2017). The pathogenicity of $P$. carotovorum subsp. brasiliense is based on the ability to produce a greater range of enzymes, such as pectate lyase, polygalacturonase, cellulase, and proteases, that confers virulence factors to degrade structural components of the cell wall and infect the host (Lee et al. 2014; Toth and Birch 2005). The main goal of this research was to identify the causal agent of tetecho rot. Future studies should focus on the genetic variability and differences in virulence and aggressiveness of these isolates.

Phenotypical characterization allowed us to differentiate the bacteria isolated from tetecho from the most common pectinolytic Enterobacteriaceae and identify them as $P$. carotovorum subsp. brasiliense (Czajkowski et al. 2015; Schaad et al. 2001). In addition, this research provides information on sensitivity of $P$. carotovorum subsp. brasiliense to antibiotics and its ability to tolerate $7 \% \mathrm{NaCl}$ in $\mathrm{NB}$ and CPG medium. To verify phenotypical identification, $16 \mathrm{~S}$ rDNA, IGS 16S-23S rDNA, and rpoS genes were amplified and sequenced. The $16 \mathrm{~S}-23 \mathrm{~S}$ intergenic region and rpoS gene have been successfully used to separate $P$. carotovorum subsp. brasiliense from other related pectinolytic bacteria (Duarte et al. 2004; Waleron et al. 2002). Analysis of the rpoS gene sequences of these isolates showed them to be in the same cluster with P. carotovorum subsp. brasiliense (Fig. 4). The same gene also shows diversity among these 10 tetecho isolates that may be useful for future research focused on the analysis of the diversity of this pathogen.

The genus Pectobacterium is considered a heterogeneous group with genetic diversity. Phylogenetic analysis of eight conserved genes using strains of $P$. carotovorum subsp. brasiliense identified two clusters that were explained based on their geographical origin (Lee et al. 2014; Nabhan et al. 2012). This heterogeneity was also detected in the bacteria as a pathogen, since different virulence and aggressiveness has been detected in pathogenicity tests in potato plants (Marquez-Villavicencio et al. 2011).

Few studies have addressed soft rot in columnar cacti in the world. Alcorn et al. (1991) studied pectinolytic bacteria that cause soft rot of saguaro cactus (Carnegiea gigantea) in Arizona and Texas, U.S.A., and northern Mexico. Using fatty acid profiles, Alcorn et al. (1991) were able to identify Pectobacterium (Erwinia) cacticida as a new species within most common pectinolytic bacteria such as $P$. atrosepticum and P. carotovorum. Martínez et al. (2011) identified Pectobacterium by sequencing total DNA extracted from necrotic tissue of the columnar cactus Isolatocereus dumortieri and the intestine of Copestylum larvae (Diptera, Syrphidae) associated with this necrotic tissue. Martínez et al. (2011) suggested that bacteria and yeast colonize cacti that are damaged, stressed (mainly due to environmental factors), or senescent. Bacteria and yeast cause lysis of plant cells, exposing cellular content and creating an environment that attracts insects.

Pectobacterium may establish a close relationship with insects (Basset et al. 2000; Muniz et al. 2007). The necrotic tissue of Stenocereus gummosus serves as a food and reproduction substrate for Drosophila mojavensis, an endemic fly in the Mexican Sonoran desert (Fogleman and Foster 1989). Further studies showed that four endemic species of Drosophila fed and reproduced on necrotic tissue of five columnar cactus species. A high frequency of facultative anaerobic bacteria within the Enterobacteriaceae family in the necrotic tissue was also observed (Fogleman and Danielson 2001).

In Zapotitlan Salinas Valley, Puebla, Mexico, the pathosystem tetecho-P. carotovorum subsp. brasiliense involves at least three insect orders: two Coleoptera and one Diptera (unpublished data). It has been suggested that insects introduce and disperse the pathogen (Tovar 2011); however, there is no information about the role of insects as possible vectors of $P$. carotovorum subsp. brasiliense. Further research exploring the role of insects in the development of soft rot in tetecho is necessary to understand the pathosystem and to design an integrated disease management program.

To the best of our knowledge, this is the first report of $P$. carotovorum subsp. brasiliense as a cactus pathogen in the world. It is possible that $P$. carotovorum subsp. brasiliense and tetecho have coevolved over a long period of time in Zapotitlan Salinas Valley and that the bacterium has been in Mexico for a long time. Pathogenicity in many hosts of $P$. carotovorum subsp. brasiliense represents a risk for agriculture and cactacea biodiversity in Mexico.

\section{Acknowledgments}

The authors thank the ethnic community at Valley of Zapotitlan Salinas, Puebla for the facilities granted during the sampling. The authors would like to express their appreciation to Dr. Annette Wszelaki at the University of Tennessee, Knoxville for her constructive suggestions during the reviewing of this research work.

\section{Literature Cited}

Alcorn, S. M., Orum, T. V., Steigerwalt, A. G., Foster, J. L. M., Fogleman, J. C., and Brenner, D. J. 1991. Taxonomy and pathogenicity of Erwinia cacticida sp. nov. Int. J. Syst. Bacteriol. 41:197-212.

Altschul, S. F., Gish, W., Miller, W., Myers, E. W., and Lipman, D. J. 1990. Basic local alignment search tool. J. Mol. Biol. 215:403-410.

Arias, S., Valverde, T., Zavala-Hurtado, A., and Hernández, C. 2017. Neobuxbaumia tetetzo. IUCN Red List of Threatened Species 2017:e. T152584A121540963.

Basset, A., Khush, R. S., Braun, A., Gardan, L., Boccard, F., Hoffmann, J. A., and Lemaitre, B. 2000. The phytopathogenic bacteria Erwinia carotovora infects Drosophila and activates an immune response. PNAS 97:3376-3381.

Choi, O., and Kim, J. 2013. Pectobacterium carotovorum subsp. brasiliense causing soft rot on Paprika in Korea. J. Phytopathol. 161:125-127.

Czajkowski, R., Pérombelon, M. C. M., Jafra, S., Lojkowska, E., Potrykus, M., van der Wolf, J. M., Sledz, W., and Czajkowski, C. R. 2015. Detection, identification and differentiation of Pectobacterium and Dickeya species causing potato blackleg and tuber soft rot: a review. Ann. Appl. Biol. 166: 18-38.

De Boer, S. H., Li, X., and Ward, L. J. 2012. Pectobacterium spp. associated with bacterial stem rot syndrome of potato in Canada. Phytopathology 102:937-947. 
Duarte, V., De Boer, S. H., Ward, L. J., and De Oliveira, A. M. R. 2004. Characterization of atypical Erwinia carotovora strains causing blackleg of potato in Brazil. J. Appl. Microbiol. 96:535-545.

Eden, P. A., Schmidt, T. M., Blakemore, R. P., and Pace, N. R. 1991. Phylogenetic analysis of Aquaspirillum magnetotacticum using polymerase chain reactionamplified 16S rRNA-Specific DNA. Int. J. Syst. Bacteriol. 41:324-325.

Fogleman, J. C., and Danielson, P. B. 2001. Chemical interactions in the cactusmicroorganism- Drosophila Model System of the Sonoran Desert. Am. Zool. 41:877-889.

Fogleman, J. C., and Foster, J. L. 1989. Microbial colonization of injured cactus tissue (Stenocereus gummosus) and its relationship to the ecology of cactophilic Drosophila mojavensis. Appl. Environ. Microbiol. 55:100-105.

Gillis, A., Santana, M. A., Rodríguez, M., and Romay, G. 2017. First report of bell pepper soft-rot caused by Pectobacterium carotovorum subsp. brasiliense in Venezuela. Plant Dis. 101:1671.

Godínez, A. H. O. 2011. El tetecho: Historia natural de una cactácea columnar del centro de México. Rev. Acad. Mex. Cienc. 52:52-57.

Jaramillo, A., Huertas, C. A., and Gómez, E. D. 2017. First report of bacterial stem rot of tomatoes caused by Pectobacterium carotovorum subsp. brasiliense in Colombia. Plant Dis. 101:830.

Lee, D. H., Kim, J.-B., Lim, J.-A., Han, S.-W., and Heu, S. 2014. Genetic diversity of Pectobacterium carotovorum subsp. brasiliense isolated in Korea. Plant Pathol. J. 30:117-124.

Leonor, C., and Sierra, J. 2011. Las cactáceas mexicanas y los riesgos que enfrentan. Revista Digital Universitaria, vol. 12. http://www.revista.unam.mx/ vol.12/num1/art04/index.html

Marquez-Villavicencio, M. P., Groves, R. L., and Charkowski, A. O. 2011. Soft rot disease severity is affected by potato physiology and Pectobacterium taxa. Plant Dis. 95:232-241.

Martínez, F. A. P., Durbán, A., Latorre, A., Antón, J., and Marcos-García, M. Á. 2011. Bacteria associated with Copestylum (Diptera, Syrphidae) larvae and their cactus host Isolatocereus dumortieri. PLoS One 6:e27443.

Muniz, C. A., Jaillard, D., Lemaitre, B., and Boccard, F. 2007. Erwinia carotovora Evf antagonizes the elimination of bacteria in the gut of Drosophila larvae. Cell. Microbiol. 9:106-119.

Nabhan, S., De Boer, S. H., Maiss, E., and Wydra, K. 2012. Taxonomic relatednees between Pectobacterium carotovorum subsp. carotovorum, Pectobacterium carotovorum subsp. odoriferum and Pectobacterium carotovorum subsp. brasiliense subsp. nov. J. Appl. Microbiol. 113:904-913.

Nunes Leite, L., de Haan, E. G., Krijger, M., Kastelein, P., van der Zouwen, P. S., van den Bovenkamp, G. W., Tebaldi, N. D., and van der Wolf, J. M. 2014. First report of potato blackleg caused by Pectobacterium carotovorum subsp. brasiliense in the Netherlands. New Dis. Rep. 29:24.

Onkendi, E. M., Ramesh, A. M., Kwenda, S., Naidoo, S., and Moleleki, L. 2016. Draft genome sequence of a virulent Pectobacterium carotovorum subsp. brasiliense isolate causing soft rot of cucumber. Braz. J. Microbiol. 4 e01530-15. https://dx.doi.org/10.1128/genomeA.01530-15

Panda, P., Fiers, M. A. W. J., Armstrong, K., and Pitman, A. R. 2012. First report of blackleg and soft rot of potato caused by Pectobacterium carotovorum subsp. brasiliense in New Zealand. New Dis. Rep. 26:15.

Ruedas, M., Valverde, T., and Zavala-Hurtado, J. A. 2006. Analysis of the factors that affect the distribution and abundance of three Neobuxbaumia species (Cactaceae) that differ in their degree of rarity. Acta Oecol. 29:155-164.

Schaad, N. W., Jones, J. B., and Chun, W., eds. 2001. Laboratory guide for identification of plant pathogenic bacteria. American Phytopathological Society, St. Paul, MN.

Stommel, J. R., Goth, R. W., and Kathleen, S. H. 1996. Pepper (Capsicum annum) soft rot caused by Erwinia carotovora subsp. atroseptica. Plant Dis. 80: 1109-1112.

Tamura, K., Stecher, G., Peterson, D., Filipski, A., and Kumar, S. 2013. MEGA6: Molecular Evolutionary Genetics Analysis Version 6.0. Mol. Biol. Evol. 30: 2725-2729.

Toth, I. K., and Birch, P. R. 2005. Rotting softly and stealthily. Curr. Opin. Plant Biol. 8:424-429.

Tovar, D. C. 2011. Insectos y patógenos que afectan las áreas arboladas de Puebla. In: La Biodiversidad en Puebla: Estudio de Estado México. CONABIO, Mèxico.

van der Merwe, J. J., Coutinho, T. A., Korsten, L., and van der Waals, J. E. 2010 Pectobacterium carotovorum subsp. brasiliense causing blackleg on potatoes in South Africa. Eur. J. Plant Pathol. 126:175-185.

van der Wolf, J. M., de Haan, E. G., Kastelein, P., Krijger, M., de Haas, B. H., Velvis, H., Mendes, O., Kooman-Gersmann, M., and van der Zouwen, P. S. 2017. Virulence of Pectobacterium carotovorum subsp. brasiliense on potato compared with that of other Pectobacterium and Dickeya species under climatic conditions prevailing in the Netherlands. Plant Pathol. 66 571-583.

Waleron, K., Waleron, M., Podhajska, A. J., and Łojkowska, E. 2002. Genotyping of bacteria belonging to the former Erwinia genus by PCR-RFLP analysis of a recA gene fragment. Microbiol. 148:583-595.

Waleron, M., Waleron, K., and Lojkowska, E. 2015. First Report of Pectobacterium carotovorum subsp. brasiliense Causing soft rot on potato and other vegetables in Poland. Plant Dis. 99:1271. 